\title{
A Comparison of Cell Wall Disruption Techniques for the Isolation of Intracellular Metabolites from Pleurotus and Lepista sp.
}

\author{
Rilka M. Taskova ${ }^{\mathrm{a}, \mathrm{b}}$, Holger Zorn ${ }^{\mathrm{a}}$, Ulrich Krings ${ }^{\mathrm{a}}$, Henning Bouws ${ }^{\mathrm{a}}$, and Ralf \\ G. Berger ${ }^{\mathrm{a}, *}$ \\ a Institut für Lebensmittelchemie, Universität Hannover, D-30453 Hannover, Germany. \\ Fax: +49-511-762-4547. E-mail: rg.berger@lci.uni-hannover.de \\ b Institute of Botany, Bulgarian Academy of Sciences, 1113 Sofia, Bulgaria \\ * Author for correspondence and reprint requests \\ Z. Naturforsch. 61c, 347-350 (2006); received December 23, 2005/February 17, 2006
}

Different techniques were compared for their effectiveness in the disruption of the rigid cell walls of Basidiomycetes. Grinding under liquid nitrogen, stirred glass bead milling and enzymatic cell lysis were applied to the mycelia of Pleurotus sapidus and Lepista irina grown submerged. Each of the disruption procedures was evaluated by testing the quantity and quality of released intracellular metabolites: DNA, RNA, enzymes, and secondary metabolites. The most suitable method for nucleic acid isolation was grinding under liquid nitrogen, while bead mill homogenization was the superior technique for isolation of active enzymes. A new effective method is proposed for isolation of secondary metabolites with the aid of bead milling of fungal mycelia.

Key words: Basidiomycetes, Cell Disruption

\section{Introduction}

Basidiomycetes properties and wide range of application have led to a significant interest and intensive investigation of their systematics, ecology, genetics, molecular biology and biochemistry (Horner et al., 1998; Wasser and Weis, 1999; Pointing, 2001). Disruption of fungal cells has appeared as the first critical step in molecular biology, enzymology and biochemical investigations. Several works have dealt with the comparison of different cell disintegration techniques for isolation of DNA from ascomycetous fungi (van Burik et al., 1998; Haugland et al., 1999; Kabir et al., 2003). However, the cell disruption procedures suitable for Basidiomycetes have been scarcely studied. Their rigidity, specific cell wall composition and growth mode have been the major limitations for utilization of common procedures (Reader and Broda, 1988; Baldrian et al., 1999; Taubert et al., 2000).

Grinding under liquid nitrogen, glass bead milling and enzymatic cell lysis methods were applied to the mycelia of two Basidiomycetes, Pleurotus sapidus and Lepista irina, and monitored by evaluation of the quantity and quality of released intracellular metabolites: DNA, RNA, proteins and secondary metabolites. The aim was to assess the most suitable disintegration technique for each of the analytical approaches applied in fungal investi- gations, genomics, transcriptomics, proteomics, or metabolomics.

\section{Experimental}

\section{Strains and cultures}

The fungal strains, Pleurotus sapidus (DSMZ 8266) and Lepista irina (CBS 458.79), were grown submerged in a glucose-yeast extract broth (GYB; Onken and Berger, 1999). Homogenized mycelium was inoculated into $100 \mathrm{ml}$ GYB in $300 \mathrm{ml}$ Erlenmeyer flasks and incubated for $5 \mathrm{~d}$ at $24{ }^{\circ} \mathrm{C}$ and an agitation speed of $130 \mathrm{rpm}$. Mycelia were harvested by centrifuging at $1,000 \times g$ for $10 \mathrm{~min}$ at $4{ }^{\circ} \mathrm{C}$ (Varifuge $22 \mathrm{RS}$ equipped with rotor HFA 22.50, Heraeus, Osterode, Germany).

\section{Cell disruption}

Grinding under liquid nitrogen

Aliquots of wet mycelia in $1.5 \mathrm{ml}$ tubes were placed in a container with liquid nitrogen for $5 \mathrm{~min}$. The frozen samples were transferred into a sterile pre-cooled mortar and ground under liquid nitrogen with a pestle. The buffer required for each of the test experiments [1.) potassium phos-

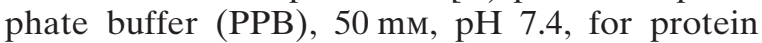
analysis or 2.) commercially supplied buffer for nucleic acid analysis] was added to the powder, 
mixed thoroughly and transferred to a microcentrifuge tube. Cell debris was pelleted by centrifugation at $15,800 \times g$ for $5 \mathrm{~min}$ at room temperature using a $5415 \mathrm{C}$ centrifuge (Eppendorf, Hamburg, Germany).

Bead mill homogenization

The container of a Dyno-Mill (Bachofen, Basel, Switzerland) was filled with $80 \mathrm{ml}$ acid-washed $0.25-0.5 \mathrm{~mm}$ diameter glass beads (Roth, Karlsruhe, Germany) and $20 \mathrm{~g}$ wet mycelia. $30 \mathrm{ml}$ buffer were added: 1.) Tris [tris(hydroxymethyl)aminomethane]-HCl buffer, $50 \mathrm{~mm}, \mathrm{pH} 8$, for nucleic acid analysis; 2.) PPB, $50 \mathrm{~mm}, \mathrm{pH} 7.4$, for protein analysis; or 3.) methanol for metabolic analysis. The samples were milled for $15 \mathrm{~min}$ at $4{ }^{\circ} \mathrm{C}$ at maximum speed. The glass beads and cell debris were pelleted by centrifugation at $2,000 \times g$ for 5 min at $4{ }^{\circ} \mathrm{C}$ (Varifuge $22 \mathrm{RS}$ equipped with rotor HFA 22.50, Heraeus) and aliquots corresponding to 100 and $300 \mathrm{mg}$ of disintegrated mycelia were taken from the supernatant for analysis.

Enzymatic cell lysis

For the protein analysis, $100 \mathrm{mg}$ wet mycelia were suspended in $2 \mathrm{ml}$ buffer containing $0.05 \mathrm{M}$ PPB (pH 7.4), $0.1 \% \quad \beta$-mercaptoethanol and $\sim 300$ U lyticase (Sigma, Steinheim, Germany). Samples were incubated at $30{ }^{\circ} \mathrm{C}$ for $30 \mathrm{~min}$ and then centrifuged at $300 \times g$ for 5 min $(5415 \mathrm{C}$, Eppendorf) to pellet spheroplasts. The supernatant was discarded by pipetting, replaced by $0.5 \%$ Triton X-100 solution and incubated for $15 \mathrm{~min}$ at $30{ }^{\circ} \mathrm{C}$ to lyse spheroplasts. Tubes were then centrifuged at $15,800 \times g$ and the lysates transferred to a clean tube.

For the nucleic acid analyses, $100 \mathrm{mg}$ wet mycelia were suspended in $2 \mathrm{ml}$ buffer containing $1 \mathrm{M}$ sorbitol, 0.1 м EDTA ( $\mathrm{pH} 7.4$ ), $0.1 \% \beta$-mercaptoethanol and $\sim 300 \mathrm{U}$ lyticase. Samples were incubated at $30^{\circ} \mathrm{C}$ for $60 \mathrm{~min}$ and centrifuged at $300 \times g$ for $5 \mathrm{~min}$ (5415 C, Eppendorf). The supernatant was discarded by pipetting, replaced by the lytic buffer from the commercially supplied kit and spheroplast lysis followed the manufacturer's protocol.

\section{Testing effectiveness of the cell disruption}

Nucleic acid isolation and detection

DNA was extracted from $200 \mathrm{mg}$ of disintegrated mycelia by a NucleoSpin Plant DNA purification kit (Macherey and Nagel, Düren, Ger- many) and RNA from $100 \mathrm{mg}$ disintegrated mycelia using the RNeasy Plant Mini Kit (Qiagen, Hilden, Germany). The nucleic acid concentrations were quantified at $260 \mathrm{~nm}$ with a Lambda 12 UV/Vis Spectrometer (Perkin Elmer, Überlingen, Germany) and their quality was tested by an Agilent 2100 bioanalyzer (Agilent, USA) and PCR and RT-PCR analyses using standard procedures (Sambrook and Russell, 2001) and a laccase sequence (Linke et al., 2005).

\section{Determination of soluble protein}

Water-soluble protein concentrations were determined by the method of Lowry et al. (1951) using the Bio-Rad $\mathrm{D}_{\mathrm{C}}$ Protein Assay (Bio-Rad, Munich, Germany). Absorption was measured at $750 \mathrm{~nm}$ with a Lambda $12 \mathrm{UV} / \mathrm{Vis}$ Spectrometer (Perkin Elmer).

\section{Enzyme activity assays}

The enzyme activity of catalase (EC 1.11.1.6) and glucose-6-phosphate dehydrogenase (EC 1.1.1.49; G-6-PD) was measured according to the methods described by Aebi (1983) and Deutsch (1983). Changes in absorption were monitored on a Lambda $12 \mathrm{UV} / \mathrm{Vis}$ Spectrometer and activity was calculated using UV-Winlab software (Perkin Elmer).

\section{Metabolite profiling}

The samples obtained by 24-h- and 5-day-extraction of mycelia with methanol and after bead mill homogenization were filtered, concentrated and purified on silica gel columns (Silica gel 60, 0.040-0.063 mm, Merck, Germany). Low-molecular-weight compounds were screened by HPLC (Jasco, Japan) with DAD (Jasco MD-910 multi wavelength detector, Jasco, Japan) and ELSD (Sedex 55, Sedere, Alfortville, France), LC/MS (Shimadzu LC-MS-QP $8000 \alpha$ system, Japan), and GC/MS (HP 5890 Series II gas chromatograph coupled to a HP quadrupole mass spectrometer 5989 A, Hewlett-Packard, USA).

\section{Results and Discussion}

\section{Nucleic acid isolation}

Samples of DNA in detectable amounts were obtained only by grinding the mycelia under liquid nitrogen (Table I). The RNA obtained after grinding under liquid nitrogen was of high integrity as proven by an Agilent 2100 bioanalyzer, PCR and RT-PCR analyses. Agarose gel electrophoresis 
Table I. Nucleic acid yield obtained by three disruption methods from Pleurotus sapidus and Lepista irina.

\begin{tabular}{lcc}
\hline Species/method & $\begin{array}{c}\text { DNA yield } \\
{\left[\mu \mathrm{g} \mathrm{g}^{-1}\right]}\end{array}$ & $\begin{array}{c}\text { RNA yield } \\
{\left[\mu \mathrm{g} \mathrm{g}^{-1}\right]}\end{array}$ \\
\hline $\begin{array}{l}\text { Pleurotus sapidus } \\
\text { Grinding under liquid nitrogen }\end{array}$ & $9.1 \pm 2.4$ & $95.5 \pm 31.8$ \\
Bead mill homogenization & $-*$ & $57.0 \pm 25.4$ \\
Lyticase cell lysis & - & - \\
Lepista irina & & \\
Grinding under liquid nitrogen & $8.1 \pm 1.6$ & $109.0 \pm 37.5$ \\
Bead mill homogenization & - & $104.0 \pm 11.3$ \\
Lyticase cell lysis & - & - \\
\hline
\end{tabular}

*No detectable amounts of DNA/RNA in the sample.

showed shearing of the RNA extracted by bead mill homogenization and the lyticase cell lysis method gave no detectable amounts of RNA. Grinding under liquid nitrogen appeared to be the superior method and lyticase cell lysis the least efficient for isolation of nucleic acid. Degradation of the isolated RNA after the bead milling process was most probably due to the specific parameters of the used Dyno-Mill which allowed disruption of high amounts of fungal material but did not provide an effective maintaining of RNA-free environment.

\section{Protein isolation}

The protein release was measured using the method of Lowry et al. (1951), and denaturation effects of the applied cell degradation methods were evaluated by monitoring the activity of catalase and glucose-6-phosphate dehydrogenase enzymes (Table II). Enzymatic cell lysis gave the least satisfactory results. As it was also expensive and time-consuming, it was considered as the inferior technique applied to protein isolation. Both, grinding under liquid nitrogen and bead mill homogenization, gave a significant overall yield of active intracellular enzymes. However, the fast and easy cell disruption by a Dyno-Mill was the preferable technique compared to the tedious procedure of grinding under liquid nitrogen, which does not allow the isolation of high amounts of protein.

\section{Metabolite analysis}

Methanolic extracts of $P$. sapidus and L. irina were obtained after $24 \mathrm{~h}$ and 5 days at room temperature and after bead mill homogenization (Table III). The samples were analyzed by high performance liquid chromatography (HPLC) with a combination of diode-array detector (DAD) and evaporative light-scattering detector (ELSD), liquid chromatography-mass spectrometry (LC/ MS), and gas chromatography-mass spectrometry (GC/MS) and found to contain monosaccharides, sugar alcohols, fatty acids, sterols, ceramides, and terpenes. Glass bead milling in methanol showed lower yields compared to the simple extraction procedures (Table III) which could be explained

Table III. Yield (\%)* of $\mathrm{MeOH}$ extracts from Pleurotus sapidus and Lepista irina.

\begin{tabular}{lcc}
\hline & Pleurotus sapidus & Lepista irina \\
\hline 24-h-extraction & 1.43 & 1.62 \\
5-d-extraction & 1.55 & 1.68 \\
Bead mill extraction & 1.37 & 1.37 \\
\hline
\end{tabular}

* Yield (\%), (weight of crude methanolic extract/wet weight of mycelia at start $) \times 100$.

Table II. Protein yield and enzyme activity after grinding under liquid nitrogen, bead mill homogenization, and enzymatic cell lysis of mycelia of $P$. sapidus and $L$. irina.

\begin{tabular}{|c|c|c|c|c|c|}
\hline \multirow[t]{2}{*}{ Species/method } & \multirow{2}{*}{$\begin{array}{l}\text { Protein yield } \\
\qquad\left[\mathrm{mg} \mathrm{g}^{-1}\right]\end{array}$} & \multicolumn{2}{|c|}{ G-6-PD activity } & \multicolumn{2}{|c|}{ Catalase activity* } \\
\hline & & Total [U 1-1] & Specific [ $\left.\mathrm{U} \mathrm{g}^{-1}\right]$ & Total $\left[\mathrm{mK} \mathrm{l}^{-1}\right]$ & Specific $\left[\mathrm{mK} \mathrm{g}^{-1}\right]$ \\
\hline \multicolumn{6}{|l|}{ Pleurotus sapidus } \\
\hline Grinding under liquid nitrogen & $1.4 \pm 0.2$ & $90.0 \pm 14.8$ & $202.9 \pm 66.6$ & $80.3 \pm 20.7$ & $174.5 \pm 16.3$ \\
\hline Bead mill homogenization & $1.6 \pm 0.1$ & $188.9 \pm 16.7$ & $174.6 \pm 27.7$ & $160.8 \pm 23.0$ & $148.0 \pm 25.2$ \\
\hline Lyticase cell lysis & $0.8 \pm 0.1$ & $45.6 \pm 0.4$ & $91.6 \pm 16.1$ & $28.3 \pm 22.1$ & $61.0 \pm 55.1$ \\
\hline \multicolumn{6}{|l|}{ Lepista irina } \\
\hline Grinding under liquid nitrogen & $2.4 \pm 0.01$ & $119.5 \pm 1.3$ & $152.8 \pm 1.1$ & $661.5 \pm 87.6$ & $846 \pm 114.6$ \\
\hline Bead mill homogenization & $1.7 \pm 0.01$ & $98.9 \pm 4.3$ & $88.5 \pm 3.4$ & $1589.8 \pm 268.2$ & $1424.0 \pm 274.5$ \\
\hline Lyticase cell lysis & $0.7 \pm 0.25$ & $18.6 \pm 1.9$ & $39.9 \pm 9.3$ & $11.5 \pm 3.4$ & $24.0 \pm 1.4$ \\
\hline
\end{tabular}

* K-rate constant used for catalase units since the abnormal kinetics of the enzyme (Aebi, 1983). 
by the comparatively difficult recovery of mycelia suspension from glass beads after the milling process. However, it led to the isolation of metabolites not present or present in small amounts in the simple fungal extracts. It is a fast, inexpensive technique, allowing disruption of sufficient amounts of mycelia and could be of interest as a new method for extraction of fungal metabolites.

Aebi H. (1983), Catalase. In: Methods of Enzymatic Analysis, Vol. 3 (Bergmeyer H.-U., ed.). VCH, Weinheim, pp. 273-286.

Baldrian P., Gabriel J., and Pospisek M. (1999), Improved isolation of nucleic acids from basidiomycete fungi. BioTechniques 27, 458-462.

Deutsch J. (1983), Glucose-6-phosphate dehydrogenase. In: Methods of Enzymatic Analysis, Vol. 3 (Bergmeyer H.-U., ed.). VCH, Weinheim, pp. 190-197.

Haugland R. A., Heckman J. L., and Wymer L. J. (1999), Evaluation of different methods for the extraction of DNA from fungal conidia by quantitative competitive PCR analysis. J. Microbiol. Methods 37, 165-176.

Horner W. E., Helbling A., and Lehrer S. B. (1998), Basidiomycete allergens. Allergy 53, 1114-1121.

Kabir S., Rajendran N., Amemiya T., and Itoh K. (2003), Quantitative measurement of fungal DNA extracted by three different methods using real-time polymerase chain reaction. J. Biosci. Bioeng. 96, 337-343.

Linke D., Bouws H., Peters T., Nimtz M., Berger R. G., and Zorn H. (2005), Laccase of Pleurotus sapidus: Characterization and Cloning. J. Agric. Food Chem. 53, 9498-9505.

Lowry O. H., Rosenbrough N. J., Farr A. L., and Randall, R. J. (1951), Protein measurement with Folin phenol reagent. J. Biol. Chem. 193, 165-275.

\section{Acknowledgement}

This project is part of the joint initiative "Biologisch aktive Naturstoffe - Chemische Diversität" at the University of Hannover. R. Taskova is grateful for the grant by the Deutsche Forschungsgemeinschaft. We thank Agilent Company for providing us with an Agilent 2100 bioanalyzer.

Onken J. and Berger R. G. (1999), Effects of $R$-(+)-limonene on submerged cultures of the terpene transforming basidiomycete Pleurotus sapidus. J. Biotechnol. 69, $163-168$.

Pointing S. B. (2001), Feasibility of bioremediation by white-rot fungi. Appl. Microbiol. Biotechnol. 57, 2033.

Reader U. and Broda P. (1988), Preparation and characterisation of DNA from lignin degradation fungi. Methods Enzymol. 161, 211-220.

Sambrook J. and Russell D. W. (2001), Molecular Cloning, Vol. 1-3. Cold Spring Harbour, New York.

Taubert J., Krings U., and Berger R. G. (2000), A comparative study on the disintegration of filamentous fungi. J. Microbiol. Methods 42, 225-232.

van Burik J. A., Schreckhise R. W., White T. C., Bowden R. A., and Myerson D. (1998), Comparison of six extraction techniques for isolation of DNA from filamentous fungi. Med. Mycol. 36, 299-303.

Wasser S. and Weis A. (1999), Medicinal properties of substances occurring in higher basidiomycetes mushrooms: current perspectives (review). Int. J. Med. Mushrooms 1, 31-62. 